\title{
Morphogenetic Studies of Some Genotypes of Onion (Allium cepa L.) In Jos, Nigeria
}

\author{
S. A. Sirajo ${ }^{1} \&$ O. A. T. Namo ${ }^{2}$ \\ ${ }^{1}$ Department of Botany, Faculty of Science, PMB 146, Federal University Lafia, Nasarawa State, Nigeria \\ ${ }^{2}$ Cytogenetics and Plant Breeding Unit, Department of Plant Science and Technology, University of Jos, P.M.B. \\ 2084, Jos, Plateau State, Nigeria \\ Correspondence: O. A. T. Namo, Department of Plant Science and Technology, University of Jos, P.M.B. 2084, \\ Jos, Plateau State, Nigeria. Tel: 234-803-642-4915. E-mail: akunamo@ yahoo.co.uk
}

Received: September 3, 2018 Accepted: September 21, 2018 Online Published: November 13, 2018

doi:10.5539/sar.v8n1p33 URL: https://doi.org/10.5539/sar.v8n1p33

\begin{abstract}
The improvement of the fresh bulb and the economic dry matter yields of onion is dependent on the morphogenetic variability and the interrelationships amongst morphological attributes which can be used to determine the quality or performance of the crop. This research was aimed to study the morphogenetic characteristics of ten genotypes of onion (Ares, Violet de Galmi, Red Creole, "Wase", "Dan Zaria", "Dan Garko", "Dan Giyawa", "Bahaushe", "Bakana" and "Yar Aleiro") in Jos, Plateau State. Using the seedlings raised in the nursery, the genotypes were laid out in a completely randomized design (CRD) with four replicates. Results showed that morphological attributes differed amongst the genotypes, except the number of leaves per plant, neck thickness and horizontal bulb diameter. The study concludes that morphological differences, which are responsible for differences in fresh bulb and dry matter yields, exist amongst the different genotypes of onion. These attributes could be used as selection indices in the improvement of the onion.
\end{abstract}

Keywords: morphogenetic characteristics, onion genotypes, improvement

\section{Introduction}

Onion (Allium cepa L.) belongs to the family Alliaceae. It originated in Central Asia, but can be found all over the world today. Onion is ranked second after tomato among vegetables in terms of consumption. The total world production of onions in 2013 was 4,281,501 tons, out of which 648,247 tons was produced in Africa; 267,164 tons from West Africa and 235,000 tons in Nigeria. These tonnages were obtained from 230,180 ha, 46,469 ha, 16,221 ha and 14,000 ha with average yields of $18,600.8 \mathrm{~kg} / \mathrm{ha}, 13,950.1 \mathrm{~kg} / \mathrm{ha}, 16,470.3 \mathrm{~kg} / \mathrm{ha}$ and $16,785.7$ $\mathrm{kg} / \mathrm{ha}$, from the world, Africa, West Africa and Nigeria, respectively (FAOSTAT, 2013).

Crop varieties perform differently under different agro-climatic conditions and various varieties of the same species grown even in the same environment give different yields as the performance of a cultivar mainly depends on the interaction of genetic make-up and environment (Jilani \& Ghafoor, 2003). Like many other crops, the productivity of onion depends on growth attributes such as leaf area, leaf area index and crop growth rate (Abou El-Magd, 2013). Growth analysis is a useful technique in the study of plants, because it bridges the gap between the empirical and the mechanistic approaches to modeling growth and development, which is a necessary prerequisite for the understanding of the morphology of a plant (Abou El-Magd, 2013). Ijoyah, Rakotomavo and Naikem (2008) observed that some varieties of onion performed better than the commonly grown ones in Seychelles. Morphological studies are basically used to determine the quality and performance of a crop plant.

Therefore, in order to enhance the commercial production of onion to meet increasing demand, an understanding of the onion morphology may be used to establish the distinctiveness of the individual genotypes. The objective of this study was to determine the variation in the morphological characteristics of some genotypes of onion grown in Jos, Plateau State. 


\section{Materials and Methods}

\subsection{Raising of Seedlings in the Nursery}

The seedlings of the genotypes were raised in the Green House of the Federal College of Forestry, Jos, Plateau State (Latitude $09^{\circ} 57^{\prime} \mathrm{N}$, Longitude $08^{0} 53^{\prime} \mathrm{E}$, Altitude $1,159 \mathrm{~m}$ above sea level) Topsoil, sharp sand and organic manure (cow dung) in the ratio of 2:1:1 were thoroughly mixed and set in fifteen (10) plastic trays which measured $70 \mathrm{~cm}$ in diameter, $23 \mathrm{~cm}$ in height and $23 \mathrm{~cm}$ in length. Each tray was labeled according to each genotype. Seeds of each genotype were broadcast into each tray and mulched for 7-10 days at 3-5 cm thickness of dry grass (which was removed after germination was attained at 60\%). The seedlings were transplanted after eight weeks. The genotypes were laid out in a completely randomized design (CRD) with four replicates. The agronomic characteristics of the genotypes used are shown in Table 1.

Table1. Agronomic characteristics of onion genotypes used in the study

\begin{tabular}{ll}
\hline Varieties & Agronomic characteristics \\
\hline Ares & An improved variety with red bulbs \\
Violet De Galmi & $\begin{array}{l}\text { An improved variety with light purple bulb. Tropical and strictly short-day with flattened } \\
\text { bulbs and very strong taste. Shows excellent tolerance when kept for several months. }\end{array}$ \\
$\begin{array}{l}\text { Onion Red Creole } \\
\text { Wase }\end{array}$ & $\begin{array}{l}\text { An improved onion variety with red bulbs } \\
\text { A local farmer's variety with red bulbs from Wase Local Government } \\
\text { Area of Plateau State }\end{array}$ \\
Dan Zaria & $\begin{array}{l}\text { A local variety sourced from Zaria, Kaduna State. Characterized by distinct traits, } \\
\text { which include early maturity and small bulbs. It is cultivated during the rainy season }\end{array}$ \\
Yar Giyawa & $\begin{array}{l}\text { A local variety from Gwaranyo, Sokoto State, characterized by small bulbs } \\
\text { and early maturity. It is cultivated under irrigation }\end{array}$ \\
Dan Garko & $\begin{array}{l}\text { A local variety from Kano State characterized by large dark-red bulbs and is } \\
\text { cultivated under irrigation. }\end{array}$ \\
Bahaushe & $\begin{array}{l}\text { A local variety obtained from Gwaranyo, Sokoto State and characterized by } \\
\text { large bulbs. It is cultivated under irrigation. }\end{array}$ \\
Bakana & $\begin{array}{l}\text { A local variety from Kano State, characterized by late maturity } \\
\text { and large bulbs. It is cultivated under irrigation. }\end{array}$ \\
Yar Aliero & A local variety from Kebbi State, characterized by early maturity \\
with large bulbs. It is cultivated in the rainy season
\end{tabular}

Sources: 1. Centre for Pastoral and Agricultural Research, Usmanu Dan Fodiyo University, Sokoto (Ares, Violet de Galmi, Red Creole, "Dan Zaria", "Dan Giyawa", "Dan Garko", "Bahaushe", "Bakana" and "Yar Aleiro", 2. Wase Local Government Area, Plateau State ("Wase")

\subsection{Preparation of Potting Mixture for Transplanting Seedlings}

Topsoil was collected from a fallow field and the organic manure (cow dung) used was collected from animal farm in Jos (popularly known as Yan shanu, Nasarawa Gwong, Jos). The topsoil was mixed with the organic manure in a potting ratio of 3:1. The soil mixtures were prepared by initial irrigation to provide adequate moisture, and was then analyzed for chemical and physical properties at the Agricultural Services, Training and Marketing Centre (ASTC), Kassa, Plateau State. The result of the physico-chemical properties of the soil used for the experiment is shown in Table 2. The mixtures were placed in polyethylene pots, which measured $23 \mathrm{~cm}$ in diameter and $23 \mathrm{~cm}$ in length. Each pot was perforated at the bottom to ensure proper drainage. The pots were arranged in a completely randomized design with four replicates. Transplanting was done on August 21, 2016. Seedlings were transplanted at a depth of 1-4 cm (Olani \& Fikre, 2010). Two pots represented a plot and three seedlings were planted in each pot. The pots were kept in the sun as recommended by McGee (2004) and Hanelt (1990). The experiment was rain-fed and weeding was carried out weekly. 
Table 2. Physico- chemical properties of the topsoil of the experimental site

\begin{tabular}{ll}
\hline Property & Value \\
\hline Texture class & Sandy loam \\
$\mathrm{pH}$ & 6.74 \\
Organic carbon $\left(\mathrm{g} \mathrm{kg}^{-1}\right)$ & 8.7 \\
Total Nitrogen $\left(\mathrm{g} \mathrm{kg}^{-1}\right)$ & 0.14 \\
Available Phosphorus $(\mathrm{ppm})$ & 89 \\
OM $(\%)$ & 4.82 \\
Clay & 16.16 \\
Silt & 12.00 \\
Sand & 75.84 \\
Exchangeable bases (mMol/100g) & \\
Calcium & 423 \\
Magnesium & 104 \\
Potassium & 108 \\
Sodium & 3.4 \\
Cation exchange capacity (CEC) & 3.37 \\
Analysed at ASTC, Kassa, Plateau State & \\
\hline
\end{tabular}

\section{Field Observations and Data Collection}

Field observations and data collection were carried out fortnightly after transplanting.

\subsection{Plant Height}

Plant height was measured using the metre rule from the soil surface to the top of the longest leaf.

\subsection{Number of Leaves Per Plant}

The total number of outer leaves in each plant was counted and recorded.

\subsection{Neck Diameter}

Neck diameter (thickness) was measured at the narrowest point using the Vernier caliper.

\subsection{Fresh Plant Weight}

Fresh plant weight (including leaves, bulbs and roots) was measured using a digital weighing balance (Laboratory Analytical Balance 6354 model).

\subsection{Horizontal and Vertical Bulb Diameter}

Horizontal and vertical bulb diameters (that is the height of the bulb and the average width at the widest point in the middle portion of the mature bulb) were measured using the Vernier caliper.

\subsection{Root Length}

The length of the longest root was measured, using a measuring tape.

\subsection{Bulb Shape Type and Shape Index}

Bulb shape types were identified visually by comparing the shape of the bulbs with the description by previous researchers and the use of shape index. Shape index was computed as the ratio of horizontal diameter to the vertical diameter of the bulb.

\subsection{Fresh and Dry Weight Of Bulbs}

Fresh bulbs were weighed using a digital weighing balance (Laboratory Analytical Balance 6354 model) after uprooting and washing the whole plants. The bulbs were dried for 72 hours at $80 \pm 2^{\circ} \mathrm{C}$ and thereafter weighed using the digital weighing balance (Razia, Rafiq, Jayanti, Vandria, Sheikh \& Koul, 2014). Four plants were sampled from each plot.

\section{Results and Discussion}

The significant differences observed in most of the attributes measured indicated the existence of variability among the genotypes used in this study. Alan, Mutschler, Brants, Cobb and Earl (2003) also reported genetic variability amongst genotypes of onion. 


\subsection{Mean Plant Height}

Table 3 shows plant height of some genotypes of onion grown in Jos in 2016. The genotype "Bakana" had the highest plant height of $49.00 \mathrm{~cm}$, which differed significantly $(\mathrm{P}<0.05)$ from the genotype "Dan Zaria" which was observed to be the shortest $(18.88 \mathrm{~cm})$. Plant height varied with genotype in this study. Mohanty, Hossain and Prusti (2002) observed the interaction of genotype and environment on the expression of plant height, which they noted was quantitatively inherited. Ibrahim (2010) as well as Trivedi and Dhumal (2010) also observed differences in plant height amongst onion genotypes.

\subsection{Neck Thickness}

The neck thickness ranged from $1.80 \mathrm{~cm}$ in the variety "Dan Zaria" to $4.38 \mathrm{~cm}$ in the genotypes "Bahaushe" and "Yar Aleiro" but the difference was not significant (Table 2). Whereas Ishwori, Gautam and Govinda (2016) observed no difference in neck thickness, Hirave, Wagh, Alekar and Kharde (2015) reported significant differences in neck thickness amongst the genotypes they studied as those with narrow neck thickness stored longer than those with wide neck thickness. Neck thickness is believed to influence the storability of onion.

\subsection{Number of Leaves per Plant}

The highest mean number of leaves per plant (10.5) was observed in the genotype "Bahaushe", while the lowest was observed in Violet de Galmi $(4.75 \mathrm{~cm})$. Differences in the mean number of leaves per plant among the genotypes were not significant (Table 2). Unlike plant height, the number of leaves per plant did not vary with genotype, which contradicts the reports of Boukary, Haougui, Barage, Adam, Roumba and Saadou (2012) and Dwivedi, Kushwah and Sen-Gupta (2012). It has been observed that the number of leaves in onion is also influenced by the environment (Ijoyah et al., 2008).

\subsection{Fresh Plant Weight}

Table 4 shows the effect of genotype on fresh plant weight of some genotypes of onion grown in Jos in 2016. The highest fresh plant weight (115.0 g) was observed in the genotype Violet de Galmi which differed significantly from the genotype "Dan Zaria" (62.5 g). The genotypes "Wase", "Dan Zaria" and "Dan Giyawa" did not differ significantly in fresh plant weight, with fresh plant weights of $75.8 \mathrm{~g}, 62.5 \mathrm{~g}$ and $69.5 \mathrm{~g}$, respectively. Fresh plant weight differed with genotype in this study, being highest in the genotype Violet de Galmi and lowest in the genotype "Dan Zaria". The result indicated that this attribute is genotypically controlled. The attribute is believed to define the general performance of each genotype before bulb, root and leaf separation. It is used as a major index of fresh bulb yield in the onion.

\subsection{Vertical Bulb Diameter}

The highest vertical bulb diameter was observed in the genotype Violet de Galmi $(6.6 \mathrm{~cm})$, but this did not differ significantly from genotypes Ares $(4.65 \mathrm{~cm})$ and "Wase" $(5.74 \mathrm{~cm})$. The lowest vertical bulb diameter $(3.35 \mathrm{~cm})$ was observed in the genotype "Bakana" (Table 4). Vertical bulb diameter differed significantly with genotype in this study, contrary to the result obtained by Ishwori et al. (2016), who observed that onion bulbs with high vertical bulb diameter stored longer than those with low vertical bulb diameter.

\subsection{Horizontal Bulb Diameter}

The horizontal bulb diameter varied from $3.81 \mathrm{~cm}$ in the genotype "Wase" to $6.60 \mathrm{~cm}$ in the genotype Violet de Galmi (Table 4). The differences in the horizontal bulb diameter were not significant. Onion genotypes with high horizontal bulb diameter are known to have large bulbs and small neck diameter, attributes which are believed to make them not to store well (Ishwori et al., 2016). Bulb diameter contributes to bulb size and shape index, both of which differed with genotype in this study.

\subsection{Root-length}

The highest root length of $19.4 \mathrm{~cm}$ was observed in the genotype Ares, which was followed by genotypes "Dan Zaria" $(13.9 \mathrm{~cm})$, Violet de Galmi $(12.5 \mathrm{~cm})$," Wase" $(12.1 \mathrm{~cm})$, "Yar Aleiro" $(10.0 \mathrm{~cm})$, Red Creole $(9.9 \mathrm{~cm})$, "Bahaushe" $(9.6 \mathrm{~cm})$ and "Bakana" $(9.4 \mathrm{~cm})$. The genotype "Dan Giyawa" had the shortest root-length of 9.0 $\mathrm{cm}$.

\subsection{Fresh and Dry Bulb Weights}

The highest fresh bulb weight of $76.7 \mathrm{~g}$ was observed in the genotype Red Creole, which differed significantly from genotypes 'Wase' (46.3 g), 'Bahaushe', 'Bakana' and 'Yar Aleiro' with a fresh bulb weight of $51.3 \mathrm{~g}$ (Table 4).The highest dry bulb weight of $11.60 \mathrm{~g}$ was observed in the genotype "Dan Garko" followed by genotypes "Dan Giyawa" (10.8 g), Red Creole (8.2 g), "Bahaushe" (6.7 g) and Violet de Galmi (6.0 g). The lowest dry bulb 
weight of $4.1 \mathrm{~g}$ was observed in the genotype "Wase". Like the fresh bulb weight, the dry bulb weight also differed with genotype. The genotypes with higher dry bulb weight also had higher total fresh bulb yield, implying that dry bulb weight is a major determinant of fresh bulb yield in the onion. Dry matter content has been reported to contribute largely to the firmness and tunic thickness of "Taherpuri", a local onion variety in India. Dry matter content is also believed to influence long storage period in the onion in India (Best, 2000; Mahanthesh, Ravi, Harshav, Vishnuvardhana \& Janardhan, 2008) as well as in Nigeria (Kabura, Musa \& Odo, 2008; Ibrahim, 2010). Genotypes with high dry matter have longer shelf-life and are recommended for industrial processing.

4.9 Shape Type

The genotypes Violet de Galmi, Red Creole, "Wase", "Bahaushe" and "Yar Aleiro" all had thick flat shape while the genotypes Ares and "Dan Garko" had globe and flax shapes, respectively. Both genotypes "Dan Zaria" and "Bakana" had granex shape. The genotype "Dan Giyawa" had both Spanish and granex shape (Table 5). The shape of onion bulbs is genotypically influenced, and is an important marketing attribute. Different onion shapes were observed in this study. In South Africa and for the export market, onion bulbs with a round shape are preferred for export market and by consumers (Eksteen, Van Den Klashorst \& Van, 1997; Bosch-Serra \& Currah, 2002).

\subsection{Shape Index}

The shape index in the genotype "Wase" (1.56) was statistically similar to those of genotypes Ares (1.0), Violet de Galmi (1.20), Red Creole (1.07), "Dan Zaria" (0.91) and "Dan Giyawa" (0.89). The lowest shape index of 0.74 was observed in the genotype "Dan Garko" (Table 5). An onion bulb with a shape index of $1.1 \pm 0.02$ is classified as a globe bulb, while a bulb with a $1.8 \pm 0.03$ index is regarded as a flat bulb. Those with a $1.3 \pm 0.05$ index are regarded as a flattened shape and those with a $1.1 \pm 0.02$ index are said to have a complete spherical bulb shape (Hasegawa, Bressan, Zhu \& Bohnert, 2001). Round bulbs have a shape index of 1.00 (Mallikarjun, 2006).

Table 3. Effect of genotype on plant height, number of leaves per plant and neck thickness of some genotypes of onion grown in Jos in 2016

\begin{tabular}{llll}
\hline Genotype & Plant height $(\mathbf{c m})$ & Number of leaves/Plant & Neck thickness $(\mathbf{c m})$ \\
\hline Ares & $20.83^{\mathrm{b}}$ & $5.50^{\mathrm{a}}$ & $2.43^{\mathrm{ab}}$ \\
Violet de Galmi & $19.50^{\mathrm{b}}$ & $4.75^{\mathrm{a}}$ & $1.88^{\mathrm{ab}}$ \\
Red creole & $29.25^{\mathrm{ab}}$ & $6.50^{\mathrm{a}}$ & $3.13^{\mathrm{ab}}$ \\
Wase & $35.75^{\mathrm{ab}}$ & $9.38^{\mathrm{a}}$ & $3.80^{\mathrm{ab}}$ \\
Dan Zaria & $18.88^{\mathrm{b}}$ & $5.13^{\mathrm{a}}$ & $1.80^{\mathrm{b}}$ \\
Dan Giyawa & $40.95^{\mathrm{ab}}$ & $8.78^{\mathrm{a}}$ & $3.95^{\mathrm{ab}}$ \\
Dan Garko & $37.38^{\mathrm{ab}}$ & $9.70^{\mathrm{a}}$ & $4.00^{\mathrm{ab}}$ \\
Bahaushe & $46.28^{\mathrm{a}}$ & $10.50^{\mathrm{a}}$ & $4.38^{\mathrm{a}}$ \\
Bakana & $49.00^{\mathrm{a}}$ & $9.18^{\mathrm{a}}$ & $4.33^{\mathrm{a}}$ \\
Yar Aleiro & $46.25^{\mathrm{a}}$ & $9.33^{\mathrm{a}}$ & $4.38^{\mathrm{a}}$ \\
CV $(\%)$ & 33.86 & 27.42 & 30.13 \\
\hline
\end{tabular}

Means with the same letter (s) within the same column are not significantly different at $5 \%$ level of probability (Duncan's Multiple-Range Test). 
Table 4. Effect of genotype on fresh plant weight, vertical bulb diameter, horizontal bulb diameter and root length of some genotypes of onion grown in Jos in 2016

\begin{tabular}{lllll}
\hline Genotype & $\begin{array}{l}\text { Fresh Plant } \\
\text { weight }(\mathbf{g})\end{array}$ & $\begin{array}{l}\text { Vertical bulb } \\
\text { diameter }(\mathbf{c m})\end{array}$ & $\begin{array}{l}\text { Horizontal bulb } \\
\text { diameter }(\mathbf{c m})\end{array}$ & $\begin{array}{l}\text { Root } \\
\text { Length }\end{array}$ \\
\hline Ares & $87.50^{\mathrm{ab}}$ & $4.65^{\mathrm{abc}}$ & $4.65^{\mathrm{a}}$ & $19.35^{\mathrm{a}}$ \\
Violet de Galmi & $115.00^{\mathrm{a}}$ & $6.60^{\mathrm{a}}$ & $6.60^{\mathrm{a}}$ & $12.50^{\mathrm{bc}}$ \\
Red creole & $111.67^{\mathrm{a}}$ & $3.92^{\mathrm{bc}}$ & $4.00^{\mathrm{a}}$ & $9.93^{\mathrm{bc}}$ \\
Wase & $75.75^{\mathrm{b}}$ & $5.74^{\mathrm{ab}}$ & $3.81^{\mathrm{a}}$ & $12.13^{\mathrm{bc}}$ \\
Dan Zaria & $62.50^{\mathrm{b}}$ & $3.65^{\mathrm{bc}}$ & $4.26^{\mathrm{a}}$ & $13.90^{\mathrm{b}}$ \\
Dan Giyawa & $69.50^{\mathrm{b}}$ & $4.21^{\mathrm{bc}}$ & $4.71^{\mathrm{a}}$ & $9.03^{\mathrm{c}}$ \\
Dan Garko & $83.75^{\mathrm{ab}}$ & $3.62^{\mathrm{bc}}$ & $4.97^{\mathrm{a}}$ & $9.08^{\mathrm{c}}$ \\
Bahaushe & $75.00^{\mathrm{b}}$ & $3.73^{\mathrm{bc}}$ & $4.45^{\mathrm{a}}$ & $9.58^{\mathrm{bc}}$ \\
Bakana & $70.75^{\mathrm{b}}$ & $3.35^{\mathrm{c}}$ & $4.43^{\mathrm{a}}$ & $9.43^{\mathrm{bc}}$ \\
Yar Aleiro & $63.25^{\mathrm{b}}$ & $3.41^{\mathrm{c}}$ & $4.57^{\mathrm{a}}$ & $10.00^{\mathrm{bc}}$ \\
CV $(\%)$ & 22.79 & 25.23 & 16.49 & 28.03 \\
\hline
\end{tabular}

Means with the same letter (s) within the same column are not significantly different at $5 \%$ level of probability (Duncan's Multiple-Range Test).

Table 5. Effect of genotype on fresh bulb weight, dry bulb weight, shape type and shape index of some genotypes of onion grown in Jos in 2016

\begin{tabular}{lllll}
\hline Genotype & Fresh bulb weight $(\mathbf{c m})$ & Dry bulb weight $($ g) & Shape type & Shape index \\
\hline Ares & $55.00^{\mathrm{b}}$ & $4.35^{\mathrm{c}}$ & Globe & $1.00^{\mathrm{ab}}$ \\
Violet de Galmi & $62.50^{\mathrm{ab}}$ & $6.00^{\mathrm{abc}}$ & Thick flat & $1.20^{\mathrm{ab}}$ \\
Red creole & $76.67^{\mathrm{a}}$ & $8.23^{\mathrm{abc}}$ & Thick flat & $1.07^{\mathrm{ab}}$ \\
Wase & $46.25^{\mathrm{b}}$ & $4.08^{\mathrm{c}}$ & Thick flat & $1.56^{\mathrm{a}}$ \\
Dan Zaria & $50.00^{\mathrm{b}}$ & $4.45^{\mathrm{c}}$ & Granex & $0.91^{\mathrm{ab}}$ \\
Dan Giyawa & $63.75^{\mathrm{ab}}$ & $10.79^{\mathrm{ab}}$ & Spanish and granex & $0.89^{\mathrm{ab}}$ \\
Dan Garko & $61.25^{\mathrm{ab}}$ & $11.60^{\mathrm{a}}$ & Flax & $0.74^{\mathrm{b}}$ \\
Bahaushe & $51.25^{\mathrm{b}}$ & $6.74^{\mathrm{abc}}$ & Thick flat & $0.83^{\mathrm{b}}$ \\
Bakana & $51.25^{\mathrm{b}}$ & $5.40^{\mathrm{bc}}$ & Granex & $0.76^{\mathrm{b}}$ \\
Yar Aleiro & $51.25^{\mathrm{b}}$ & $7.45^{\mathrm{abc}}$ & Thick flat & $0.77^{\mathrm{b}}$ \\
CV $(\%)$ & 16.02 & 38.24 & & 26.05 \\
\hline
\end{tabular}

Means with the same letter (s) within the same column are not significantly different at $5 \%$ level of probability (Duncan's Multiple-Range Test).

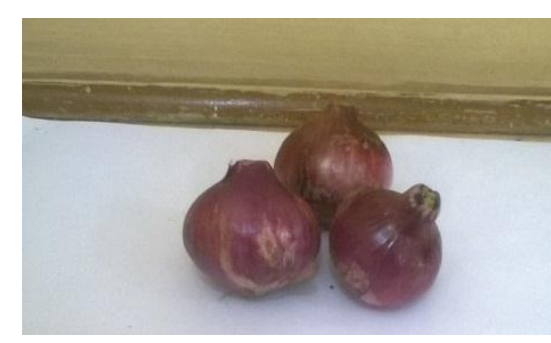

Ares

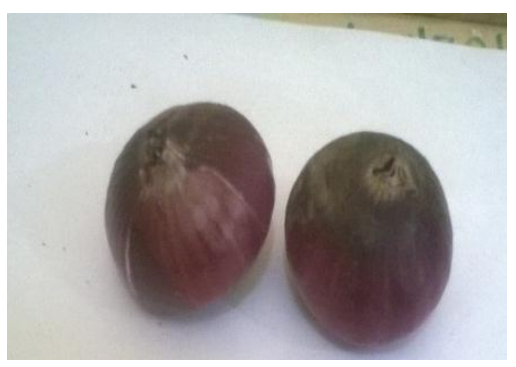

Red Creole

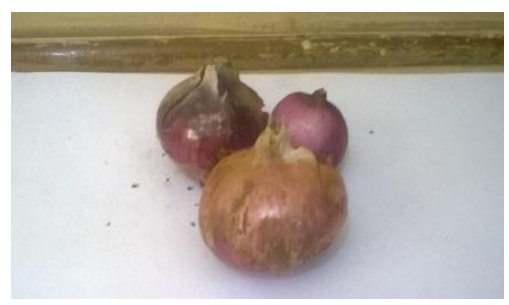

Violet de Galmi

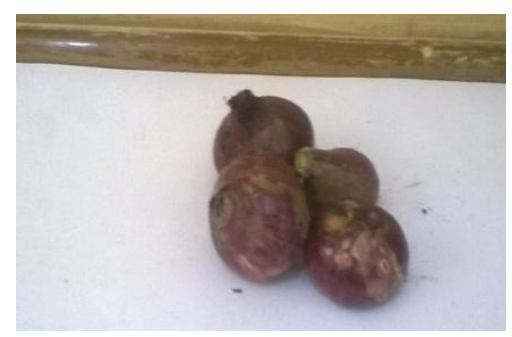

Wase 


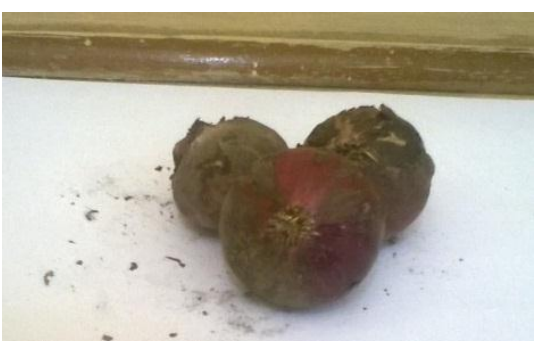

Dan Zaria

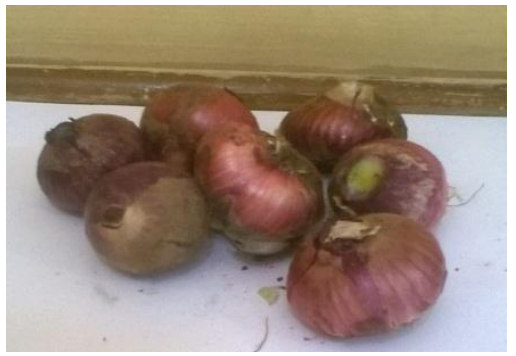

Dan Garko

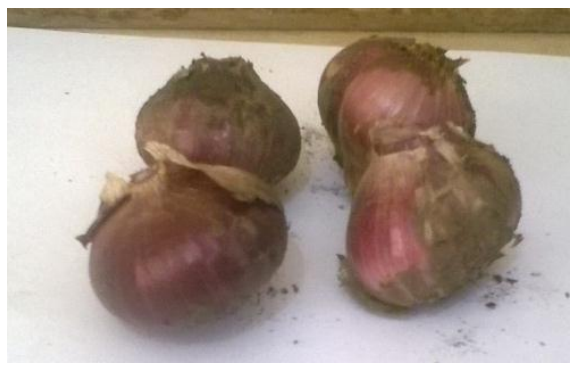

Bahaushe

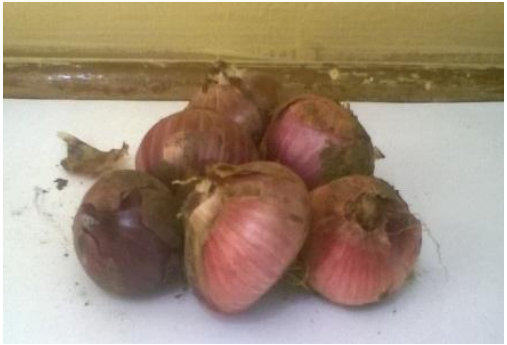

Dan Giyawa

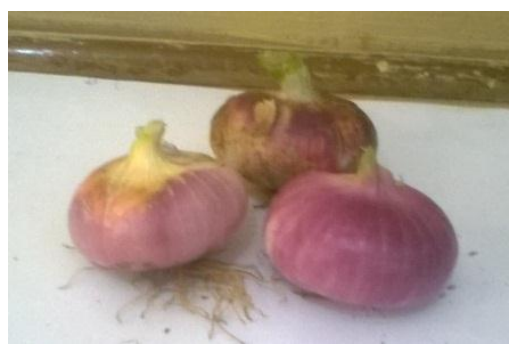

Bakana

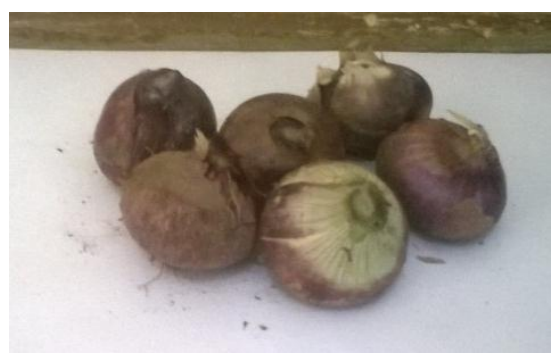

Yar Aleiro

Figure 1. different onion genotypes observed in this study

\section{Conclusion}

Results of this study showed that morphological attributes differed amongst the onion genotypes, except for the number of leaves/plant, neck thickness and horizontal bulb diameter. The study concludes that morphological differences, which are responsible for differences in fresh bulb and dry matter yields exist amongst the different genotypes of onion cultivated in Nigeria. These attributes could be used as selection indices in the improvement of the onion.

\section{Acknowledgments}

The authors thank the Centre for Pastoral and Agricultural Research, Usmanu Danfodiyo University, Sokoto and the Wase Local Government Area, Plateau State for providing the seeds of the genotypes used in this study. We also thank the Federal University, Lafia for their financial assistance.

\section{References}

Abou El-Magd, M. M., Zaki, M. F., Abd El-Al, F. S., \& Abd El-Samad, E. H. (2013). Growth analysis and chemical constituents of garlic plants in relation to morphological growth stages. Journal of Applied Sciences Research, 9(2), 1170-1180.

Alan, A. R., Mutschler, M. A., Brants, A., Cobb, E., \& Earle, E. D. (2003). Production of gynogenic plants from hybrids of Allium cepa L. and A. royleistern. Plant Science, 165, 1201-1211. https://doi.org/10.1016/S0168-9452(03)00327-3

Best, K. (2000). Red Onion Cultivars Trial. Horticultural Nova Scotia, Kentville Agricultural Centre, Nova Scotia (Canada), 10-13.

Bosch Serra, A. D., \& Currah, L. (2002). Agronomy of onions. In Rabinowitch, H. D. \& Currah, L. (Eds.). 
Allium Crop Science: Recent Advances. CAB International, Wallingford, United Kingdom. 187-197. https://doi.org/10.1079/9780851995106.0187

Boukary, H., Haougui, A., Barage, M., Adam, T., Roumba, A., \& Saadou, M. (2012). Evaluation agro-morphologique des variétés et/ouécotypeslocauxd'oignon du Niger. International Journal of Biological and Chemical Sciences, 6(6), 3098-3106.

Dwivedi, Y. C., Kushwah, S. S., \& Sengupta, S. K. (2012). Evaluation of onion varieties for growth, yield and quality traits under agro- climatic conditions of Kymore plateau region of Madhya Pradesh, Indian. Agricultural Science Digest, 32(4), 326-328.

Eksteen, G. J., Van Den Klashorst, E., \& Van, Z. B. (1997). Onions for export harvesting, handling and storage. Onions J. 2. Agricultural Research Council, Vegetable and Ornamental Plant Institute, Pretoria, South Africa. 1-2.

FAOSTAT (2013). FAOSTAT Database Results. Retrieved from http://www.faostat.org

Hanelt, P. (1990). Taxonomy, evolution and history. In Rabinowitch, H. D. \& Brewster, J. L. (Eds). Onions and Allied Crops, Botany, Physiology and Genetics. CRC Press, Boca Raton, Florida, 1-26.

Hasegawa, P. M., Bressan, R. A., Zhu, J. K., \& Bohnert, H. J. (2001). Plant cellular and molecular responses to high salinity. Annu. Rev. Plant Physiol. and Plant Mol. Biol., 51, 463-499. https://doi.org/10.1146/annurev.arplant.51.1.463

Hirave, P. S., Wagh, A. P., Alekar, A. N., \& Kharde, R. P. (2015). Performance of Red Onion Varieties in Kharif Season under Akola Conditions. Journal of Horticulture, 2, 132-135.

Ibrahim, N. D. (2010). Growth and yield of onion (Allium cepa L.) in Sokoto, Nigeria Agric. Biological Journal, 4, 556-564.

Ijoyah, M. O., Rakotomavo, H., \& Naiken, M. V. (2008). Yield performance of four onion (Allium cepa L.) varieties compared with the local variety under open field conditions at Anse Boileau, Seychelles. Journal of Science and Technology, 28(3), 28-33.

Ishwori, P., Gautam, B. K., \& Govinda, P. P. (2016). Evaluation of different varieties of onion and their transplanting times for off-season production in Mid Hills of Nepal. Nepal Agric. Res. J., 7, 23-28.

Jilani, M. S., \& Ghafoor, A. (2003). Screening of local onion varieties for bulb formation. International Journal of Agriculture and Biology, 5(2), 129-133.

Kabura, B. H., Musa, B., \& Odo, P. E. (2008). Evaluation of the yield components and yield of onion (Allium cepa L.) and pepper (Capsicum annum L.) intercrop in the Sudan Savanna. Journal of Agronomy, 7, 88-92. https://doi.org/10.3923/ja.2008.88.92

Mahanthesh, B., Ravi, P. S. M., Harshav, M., Vishnuvardhana, M., \& Janardhan, G. (2008). Evaluation of different onion (Allium cepa $\mathrm{L}$.) genotypes for yield and processing quality parameters in kharif season under irrigated condition. The Asian Journal of Horticulture, 3(1), 5-9.

Mallikarjun, N. (2006). Heterosis and combining ability studies in onion (Allium cepa L.). M.Sc. Thesis. University of Agricultural Sciences, Dharwad, India. http://www.google.co.za (accessed on 03 February 2016).

McGee, H. (2004). On Food and Cooking: The Science and Lore of the Kitchen. Amazon.com books. 23.

Mohanty, B. K., Hossain, M. M., \& Prusti, A. M. (2002). Performance of onion cultivars in kharif season. Advances in Plant Science, 15, 603-606.

Olani, N., \& Fikre, M. (2010). Onion seed production in Nigeria. A Manual for Extension Agents and Seed Producers. 1-16.

Razia, S., Rafiq, L., Jayanti, N., Vandria, S., Sheikh, I., \& Koul, K. K. (2014). Benefits of inoculation of Arbuscular-Mycorrhizal fungi on Growth and Development of onion (Allium cepa) plant. American-Eurasian Journal of Agriculture and Environmental Sciences, 14(6), 527-535.

Trivedi, A. P., \& Dhumal, K. N. (2010). Variability and correlation studies on bulb yield, morphological and storage characters in onion (Allium cepa L.). Journal of Pure and Applied Sciences, 18, 1-4. 


\section{Copyrights}

Copyright for this article is retained by the author(s), with first publication rights granted to the journal.

This is an open-access article distributed under the terms and conditions of the Creative Commons Attribution license (http://creativecommons.org/licenses/by/3.0/). 